\title{
Formation of the capital structure of metallurgical industry companies in conditions of sustainable industry development $\mathbf{4 . 0}$
}

\author{
Lu Yanzhao ${ }^{1}$, E.S. Panfilova ${ }^{2, *}$, and M.I. Lvova ${ }^{2}$ \\ ${ }^{1}$ Harbin Engineering University, Harbin, China \\ ${ }^{2}$ Ural State University of Economics, 8 Marta Str., 62, 620144 Ekaterinburg, Russia
}

\begin{abstract}
The article deals with current issues of digital transformation of metallurgical companies in the conditions of sustainable development of industry 4.0. The authors systematize the tools of through digitalization of companies in the metallurgical industry, give their characteristics, as well as proposed a mechanism for the impact of digital tools on the capital structure and financial stability. At the same time the analysis of the capital of the leading metallurgical company of Russia and the world JSC "Uralelectromed" confirms the necessity to consider the formation of the capital structure by digital methods of management in the aspect of sustainable development.
\end{abstract}

\section{Introduction}

The issues of formation and management of the capital structure of companies in the metallurgical industry in the context of sustainable development of industry 4.0 in the context of the introduction of end-to-end digital methods of management are becoming increasingly important nowadays. This trend is caused by the introduction of digital technologies, which allows to maintain a balance of financial resources of the company through automated processes in management and production structures. Moreover, the COVID-19 pandemic has provoked even more interest in the issue of transformation of companies, both in the metallurgical sector and for other industries in Russia and other countries.

At the same time, the study of the impact of digital technologies on the structure of capital and financial position of companies to date has not received wide research interest among the scientific community, as digital methods of business in Russia are in the process of development and formation of a digital code.

Thus, the relevance of the topic of the study is due to the impact of end-to-end digital technologies on the capital structure of companies in the metallurgical industry in conditions of sustainable development of the Fourth Industrial Revolution.

The purpose of the study is to identify the impact of digital business methods on the structure and cost of capital of companies in the context of industry development 4.0.

\footnotetext{
*Corresponding author:kfm-750@mail.ru
} 
The subject of the study is economic relations in terms of capital formation of companies in the metallurgical industry in a sustainable development.

The methodological basis for this research was formed by such scientific research methods as: comparative and system analysis, as well as generalization and forecasting.

The authors highlight the following scientific positions considered in the article: 1 . The paper summarizes and systematizes the tools of through digital technologies for implementation in management and production management in metallurgical companies of the Russian Federation in conditions of sustainable development of the industry 4,$0 ; 2$. the scheme of influence of through digital methods of management on the structure of capital is developed; 3. The analysis of dynamics and structure of the capital of the metallurgical company JSC "Uralelectromed" as the leader of the copper industry of the Russian Federation was carried out; 4. Based on the conducted analysis, the authors proposed to introduce digital technologies in the conditions of sustainable development, which will contribute to the expansion of the company among the market leaders, at the same time to optimize the capital structure and, as a result, to increase the value of the company as a whole.

\section{Materials and methods}

The authors point out that it is reasonable to consider the methodology of formation and management of the company's capital in the context of sustainable development of Industry 4.0 through the prism of implementation of digital methods of management in key strategically important industries, which include the metallurgical industry. This is due to the fact that untimely inclusion in the development of digital transformation processes leads to irreversible consequences both for the companies and industries, and for the state as a whole, as it increases the risk of losing competitiveness in the world markets and as a result leads to the loss of key industries for the country's economy.

At the same time, the effect of any initiative is ultimately determined by the potential growth of market share and net profit. Not for all companies, even if they are able to model their business processes in all nuances, digitalization will be profitable. In addition, if existing business rules, processes, models and systems work flawlessly, efforts to digitize them, taking into account the necessary costs and time may not make sense [1].

Digitalization of industrial production implies integration of a number of breakthrough technologies: virtual modeling, Internet of things, robotics, artificial intelligence, big data, cloud and boundary computing technologies, predictive analytics, new communication standards, etc. [2].

At the same time, in case of point implementation of digital technologies, companies should strive to introduce end-to-end digital technologies by developing road maps for their implementation. The aim is to increase the competitiveness of the company in the domestic and foreign markets by increasing the cost of business in the conditions of digital transformation. It is possible to achieve the planned result in a way:

1. Development of breakthrough technologies as a basis for technological leadership of the company;

2. Implementation and testing of production technologies, stimulating demand for DT to achieve industrial leadership in the future;

3. Removal of barriers (technological, personnel, financial, etc.) [3].

In accordance with the recommendations of the Supervisory Board of Autonomous nonprofit organization "Digital Economy", a roadmap of through digital technologies "new production technologies" was formed, which includes the following list of subtechnologies:

1. Digital Design, Mathematical Modeling and Product Lifecycle Management (SmartDesign); 
2. SmartManufacturing Technologies;

3. Manipulators and manipulation technologies [3].

The authors have systematized the possible sub-technologies and propose to consider their characteristics in the conditions of through digitalization in the companies of the Russian metallurgical sector (Table 1).

Table 1. Cross-cutting digital technologies for implementation in metallurgical companies in the context of sustainable industry development 4.0 and their components*

\begin{tabular}{|c|c|}
\hline Subtechnology & Characteristics and functional purpose of the system \\
\hline \multicolumn{2}{|c|}{ 1. Digital Design, Mathematical Modeling and Product Lifecycle Management (SmartDesign) } \\
\hline 1. Digital Twin & $\begin{array}{l}\text { It is implemented on the basis of creation and application of multilevel } \\
\text { matrix of target indicators and resource constraints, on the basis of } \\
\text { mathematical models of different classes, levels of complexity and } \\
\text { adequacy on the basis of virtual tests, application of virtual stands and } \\
\text { virtual polygons. Special attention is paid to the development and } \\
\text { implementation. }\end{array}$ \\
\hline 1.1 digital twin creation platform & $\begin{array}{l}\text { Capable of accounting for up to } 150,000 \text { targets and resource constraints, } \\
\text { using related "end-to-end" digital artificial intelligence technologies, large } \\
\text { data, distributed registries, providing intellectual property management, } \\
\text { expert support and from the first-time physical and full scale test. }\end{array}$ \\
\hline $\begin{array}{l}1.2 \\
\text { (productlifecyclemanagement) - }\end{array}$ & $\begin{array}{l}\text { The product lifecycle management system from development to utilization } \\
\text { includes: } \\
-\quad \text { marketing and market research }(\mathrm{CRM}) \text {. } \\
-\quad \text { product design and development }(\mathrm{CAE}, \mathrm{CAD}, \mathrm{CAM}, \mathrm{PDM}) \text {. } \\
-\quad \text { production planning and preparation }(\mathrm{MES}, \mathrm{PDM}) \text {. } \\
-\quad \text { production (Automatized Enterprise Control System, Automatized } \\
\quad \text { Control System of Technological Processes, ERP, } \\
\text { MRP, MRPII, SCMMES, PDM). } \\
-\quad \text { realization (CRM, PDM). }\end{array}$ \\
\hline \multicolumn{2}{|r|}{ 2. $\quad$ Smart Manufacturing technologies } \\
\hline $\begin{array}{l}\text { ERP (Enterprise } \quad \text { Resource } \\
\text { Planning) }\end{array}$ & $\begin{array}{l}\text { An information system that integrates a large amount of data on produc- } \\
\text { tion, finance, human resources of the enterprise and a number of other } \\
\text { data, allowing to react quickly to changes and optimize resources. } \\
\text { - } \quad \text { financial control. Calculation of profit and expenses, employees' } \\
\text { wages and salaries, taxes, working hours monitoring; } \\
\text { - } \quad \text { production control. Provides a single interface for monitoring and } \\
\text { control of all production: the volume of production, budget calcula- } \\
\text { tion, making forecasts, which greatly simplifies the management of } \\
\text { interaction with business partners and counterparties; } \\
\text { business process analysis. Collection, processing and provision of } \\
\text { information necessary for effective control of the enterprise and its } \\
\text { development; } \\
\text { more efficient internal communication. Prompt access of employees } \\
\text { to the necessary information. }\end{array}$ \\
\hline $\begin{array}{l}\text { MES } \\
\text { (Manufacturingexecutionsystem) }\end{array}$ & $\begin{array}{l}\text { A system that allows you to synchronize, coordinate, analyze and optimize } \\
\text { the process of production in part of: } \\
-\quad \text { reducing operating costs; } \\
-\quad \text { reduction of defect and production losses; } \\
-\quad \text { reduction of time for production (from order placement to its re- } \\
\quad \text { ceipt); } \\
-\quad \text { unloading of warehouses; } \\
-\quad \text { increasing production capacity; } \\
-\quad \text { growth of quality control; } \\
\text { increasing production volume at the same production costs. }\end{array}$ \\
\hline
\end{tabular}


Table 1. Continued

\begin{tabular}{|c|c|}
\hline $\begin{array}{l}\text { MIS } \\
\text { (Managementin } \\
\text { formationsyste } \\
\text { m) }\end{array}$ & $\begin{array}{l}\text { Collects and processes information necessary for making management decisions: } \\
\text { - centralized data storage and distribution. Employees have access to the data they need to } \\
\text { work, which helps to optimize workflow; } \\
\text { - efficient company management. Thanks to prompt access to information, as well as } \\
\text { partial data processing, it is possible to make strategic decisions that take into account } \\
\text { all possible factors; } \\
\text { - efficient personnel management. Workflow monitoring and analysis of each employee's } \\
\text { actions allow to considerably simplify HR managers; } \\
\text { - document workflow optimization. The entire array of data is stored digitally and em- } \\
\text { ployees have an access to it at any convenient moment; } \\
\text { - effective management of the company's capital. Allows access to information about all } \\
\text { sources of profit and expenses of the company in one moment. }\end{array}$ \\
\hline $\begin{array}{l}\text { PDM - } \\
\text { (ProductDataM } \\
\text { anagement) }\end{array}$ & $\begin{array}{l}\text { Provides management of information about the product, allows to create its digital layout (a } \\
\text { set of documents allowing to produce and maintain the product): } \\
-\quad \text { engineering data management (EDM) } \\
-\quad \text { productin formation management (PIM) } \\
-\quad \text { technical data management (TDM) } \\
-\quad \text { technical information management (TIM) }\end{array}$ \\
\hline \multicolumn{2}{|r|}{ 3. Manipulators and manipulation technologies } \\
\hline & 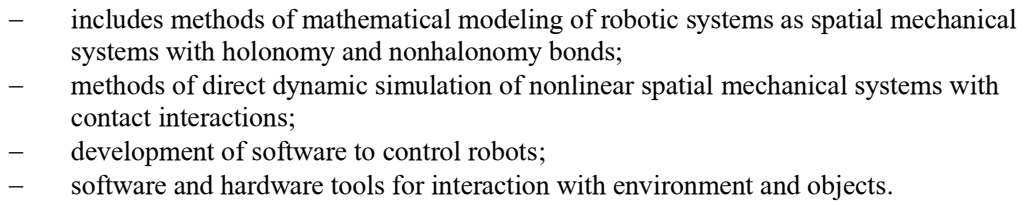 \\
\hline
\end{tabular}

* compiled by the author based on $[3,4]$

The end-to-end digital technologies presented in Table 1 are universal and are applied simultaneously with individual programs developed by each company and implemented in all parts of the production chain with significant potential for digitalization.

The authors note that the development of appropriate infrastructure requires the creation of innovation centers at enterprises, the involvement of highly qualified specialists (data scientists, data engineers, AI-architects, etc.), and a significant increase in investment in cyber security [5].

It should be noted that the main economic effect from the introduction of digital solutions is achieved provided that they are introduced directly into the production process chain. For this reason, there are no universal digital tools, as the specifics of the company's activity imply adaptation to its own production processes.

The experience of implementation of digital technologies in the conditions of sustainable development of industry 4.0 in companies of metallurgical industry shows the effectiveness of the decisions taken. Thus, in PJSC "NLMK" the main focus of digitalization is aimed at applied digital solutions providing fast economic effect. Currently there are more than 50 products of different maturity levels under development. More than half of them are at the stage of development where they are already yielding sustainable economic benefits, and the teams that work on them are focused on improving and replicating them. Digital products, used in early processing, which contribute most to the cost of production and final productivity, have significant potential in terms of efficiency [6].

In turn, the company "Rusal" JSC is implementing projects on digitalization of production. In the industrial zone in Sayanogorsk there are pilot sites for modernization of the network infrastructure, development of the technical accounting system and telemetry of power facilities, implementation of a modern production process management system (MES - systems). An automated logistics system for transport management is being 
developed at Krasnoyarsk plant. The foundry information system is also being implemented at the enterprises located in Siberia and the process control systems are being updated, 3D models of the created objects are being developed and used. To increase the efficiency of aluminum production, "Rusal" JSC is developing a control system for the electrolysis process based on predictive analytics [6].

For PJSC "Pipe Metallurgical Company" digitalization is the most important component of business strategy and an integral part of transformation processes that take place in the company. PMC has developed and implemented a concept for the development of digital technologies for 2020-2025 aimed at improving and optimizing all business processes. As part of the concept implementation, a roadmap of digital transformation projects has been compiled, which is regularly updated with new ideas and tasks. We continue to implement programs for the automation of production planning processes. It is an integrated planning system based on the cloud ERP system, which is currently being implemented in the company. The new solution will allow to automate the processes of creating and approving sales, production, purchasing and logistics plans up to 18 months in advance, which will allow to assess potential risks in advance and see additional opportunities for development [7].

"UMMC-Telecom" LLC, a part of the Ural Mining and Metallurgical Company holding, creates digital corporate products for industrial companies. The ultimate goal is to implement the instruments at the holding's own production facilities and then promote them on the foreign market, which will allow winning the competition through digitalization [8].

In 2019, PJSC MMC "Norilsk Nickel" completed implementation of SAP and ERP in all companies of the Polar Division with the participation of "NorNickel Digital Laboratory" established for this purpose. The unified system covered about 50 assets and structural divisions. Simultaneously since 2015 , the company is implementing the "Technological Breakthrough" program, which will allow in 2020 to digitize and automate the majority of production processes. The company also expects a lot from the application of block-chain technology. As a result, PJSC "NorNickel" is the only representative of Russia in the ranking of 100 investment companies in the world [9].

A review of companies in the metallurgical sector in the context of sustainable development of the industry 4.0 has confirmed the effectiveness of the introduction of digital technologies in companies' operations and prospects for their expansion in the nearest future, which will have a direct impact on the capital structure, its financial stability and the value of the company as a whole.

At the same time, the authors note that digitalization is not just a software update or a project to improve the supply chain. This is a planned "digital strike" against a fully effective system. And before starting to digitize a company, it is necessary to predict all changes with the help of business process modeling programs of different levels [10].

\section{Results and discussion}

In the context of sustainable development of the 4.0 industry in the field of digitalization of companies, special attention should be paid to the competent formation of the capital structure in order to prevent crisis consequences and ensure dynamic growth of business value, its competitiveness and investment attractiveness. Let us consider the mechanism of impact of digital technologies on the capital structure. 


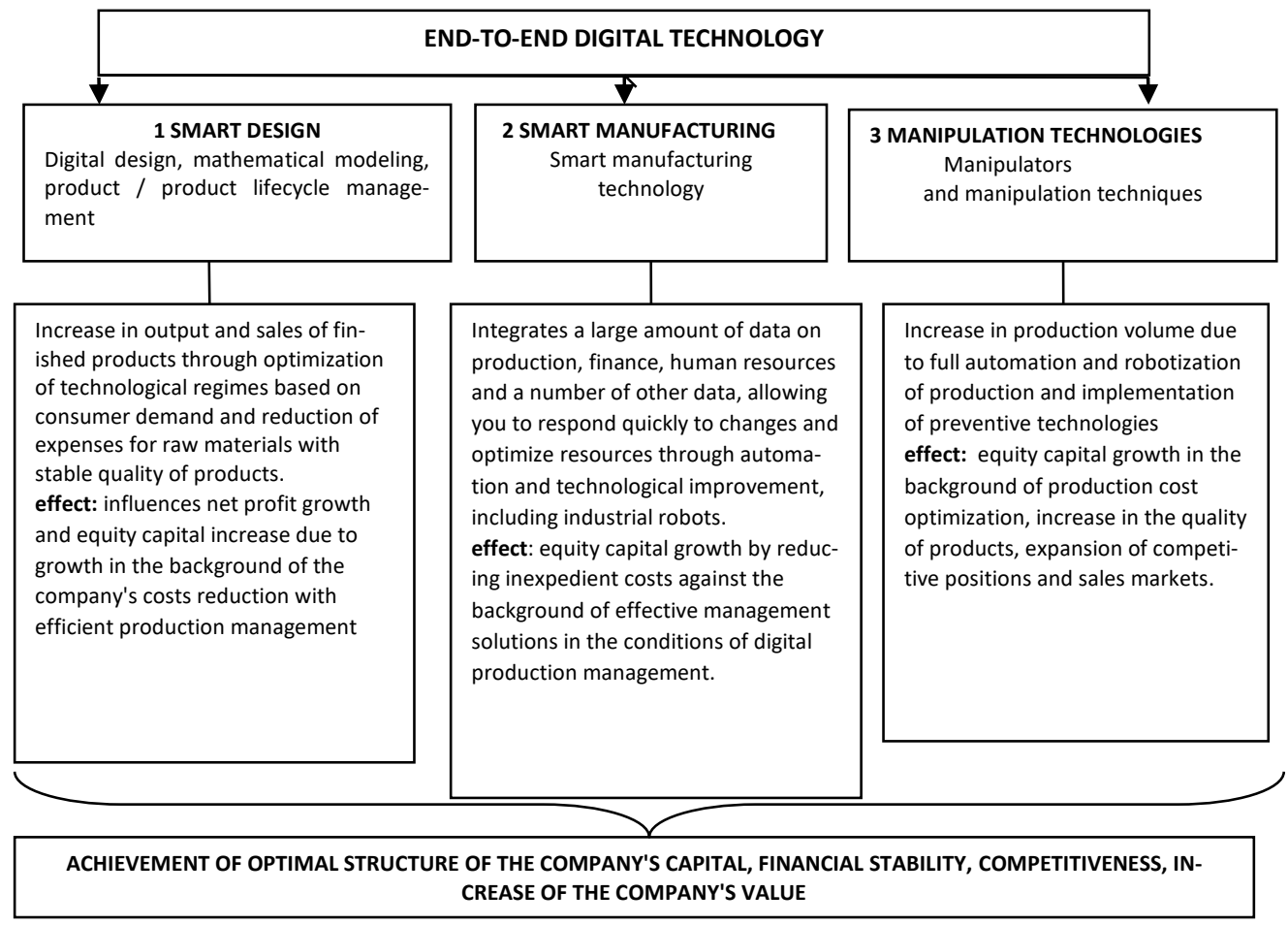

Fig. 1. Mechanism of influence of digital technologies on the capital structure of companies in the metallurgical industry in conditions of sustainable industry development 4.0 [compiled by the author on the basis of 4$]$.

Thus, it is obvious to analyze the structure and dynamics of the capital of JSC "Uralelectromed" as a key representative of the copper industry in Russia and worldwide.

Table 2. Dynamics and capital structure of JSC "Uralelectromed" for 2017-2019, thousand rub.

[compiled by the author on the basis of 11]

\begin{tabular}{|l|c|c|c|c|c|}
\hline & & & & $2018 / 2017$ & $2019 / 2018$ \\
\cline { 5 - 6 } Index & 2017 & 2018 & 2019 & \multicolumn{2}{|c|}{ Growth rate, \% } \\
\hline Equity capital & 27932455 & 27125394 & 27334048 & -3 & 1 \\
\hline $\begin{array}{l}\text { Obligations only } \\
\text { including: }\end{array}$ & 13956816 & 17772175 & 23764953 & 27 & 34 \\
\hline $\begin{array}{l}\text { Long-term loans } \\
\text { and borrowings }\end{array}$ & 5464613 & 4748389 & 3764102 & -13 & -21 \\
\hline $\begin{array}{l}\text { Short-term loans } \\
\text { and borrowings }\end{array}$ & 3517465 & 6621139 & 10569766 & 88 & 60 \\
\hline $\begin{array}{l}\text { Other short-term } \\
\text { liabilities }\end{array}$ & - & - & 1452966 & - & 100 \\
\hline D/(D+E) & 0,50 & 0,66 & 0,87 & 31 & 33 \\
\hline
\end{tabular}

According to Table 2, equity prevails in the capital structure; however, at the same time, there is an increase in short-term borrowings against the background of a decline in the company's long-term liabilities.

There are two main quantitative methods of capital structure formation in economic science, which are presented in Table 3. 
Table 3. Quantitative methods of capital structure formation

\begin{tabular}{|c|c|c|}
\hline № & Name & Formula \\
\hline 1 & $\begin{array}{l}\text { Weighted Average Cost of } \\
\text { Capital Method }\end{array}$ & $\begin{aligned} \text { WACC }= & R_{D}(1-T)^{*} \mathrm{WD}+\mathrm{RE} * \mathrm{WE} \\
\text { where: } & W A C C-\text { weighted average cost of capital; } \\
& R_{D}-\text { borrowing costs; } \\
& R_{E}-\text { cost of equity; } \\
& T-\text { ceiling rate on corporate income taxes; } \\
& W D-\text { market value of the company's debt; } \\
& W E-\text { market value of equity }\end{aligned}$ \\
\hline 2 & $\begin{array}{l}\text { Adjusted Present Value } \\
\text { Method. }\end{array}$ & $\begin{array}{c}A P V=N P V+\mathrm{PV} \\
\text { where: } \quad A P V-\text { adjusted present value; } \\
\quad N P V-\text { net present value; } \\
\quad F-\text { financing solutions }\end{array}$ \\
\hline
\end{tabular}

On the basis of calculations the WACC value for different levels of correlation between the capital structure of JSC "Uralelectromed", including the current structure of the company's capital with the share of borrowed capital equal to $45 \%$ is shown in Figure 2. According to the data, under the existing capital structure, the weighted average cost of capital is $10.25 \%$. Optimum level of financial leverage, at which the WACC level reaches a minimum between $0 \%$ and $10 \%$, and the minimum WACC value is $7.24 \%$.

Thus, according to the weighted average cost of capital model, a company should reduce its financial leverage in order to reduce capital costs and move towards an optimal capital structure.

For a more detailed analysis and to support the adequacy of WACC calculation results, let us consider the Adjusted Present Value (APV) method. The calculation of this model makes it possible to determine the capital structure in which the value of the company will be maximal considering the benefits from the tax shield and the costs of financial instability. According to the calculations and the schedule, the highest value of the company is achieved with the share of the borrowed capital equal to $40 \%$ (Fig. 3)

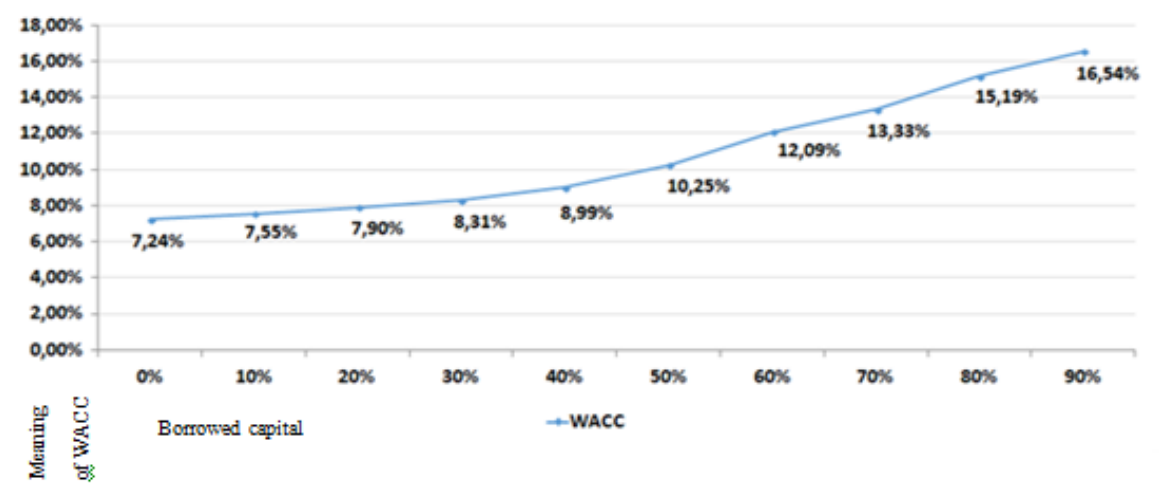

Fig 2. Graph of WACC dependence on the capital structure of "Uralelectromed" JSC, \% [compiled by the author on the basis of 11,12$]$. 


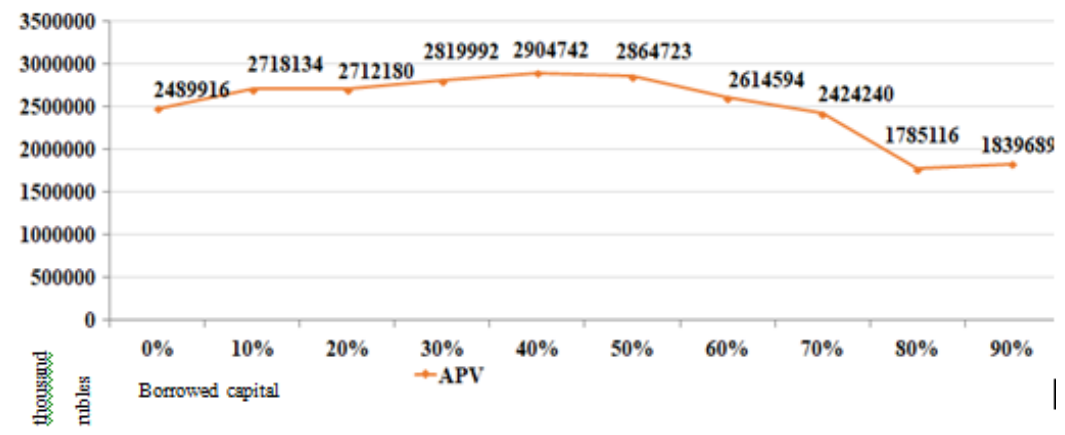

Fig 3. Schedule of changes in the present adjusted value of the company depending on the capital structure, thousand rub. [compiled by the author on the basis of 11,12 ].

Based on the results shown in the figure. 3. according to which the minimum value of WACC is reached at $0 \%$ of the borrowed capital in the general structure of the capital, and APV reaches the maximum value at the share of borrowed capital equal to $40 \%$, we can conclude that the optimal value of the capital structure in the considered case is in the range from $0 \%$ to $40 \%$.

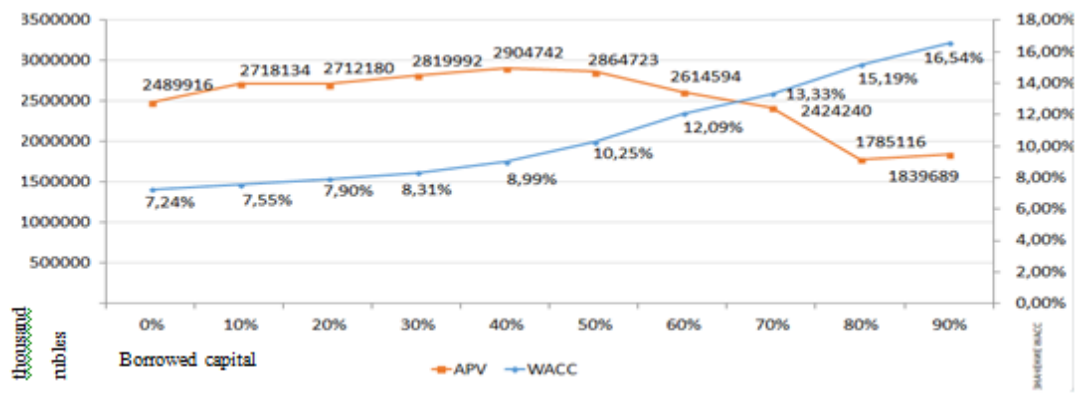

Fig 4. Dependence of WACC and APV of JSC "Uralelectromed" on the capital structure, \%, thousand rubles [compiled by the author on the basis of 11, 12].

According to the data, under the existing capital structure, the weighted average cost of capital is $10.25 \%$. The optimal level of the financial leverage at which the WACC reaches the minimum is between $0 \%$ and $10 \%$, and the minimum WACC value is $7.24 \%$.

Thus, according to the weighted average cost of capital model, a company should reduce its financial leverage in order to reduce capital costs and move towards an optimal capital structure.

According to the forecast calculations, when the capital structure changed from $55 / 45 \%$ to $60 / 40 \%$, all the most important indicators of the financial condition of the enterprise have increased, approaching the reference ideal values, which fully proves the validity of the proposed methods of capital structure optimization, and the proposed practical results of our research.

Table 5. Forecast of the most important financial coefficients of JSC "Uralelectromed" activity for 2020 by WACC and APV methods

\begin{tabular}{|l|c|c|c|}
\hline Index & Standard & 2019 & 2020 \\
\hline total liquidity ratio & $1-2$ & 0,90 & 1 \\
\hline absolute liquidity ratio & 0,15 and more & 0,04 & 0,15 \\
\hline
\end{tabular}




\begin{tabular}{|l|c|c|c|}
\hline quick liquidity ratio & 0,96 and more & 0,35 & 0,1 \\
\hline current ratio & 1,8 and more & 1,11 & 1,8 \\
\hline autonomy ratio & $0,55-0,7$ & 0,55 & 0,68 \\
\hline net worth ratio & 0,1 and more & $-0,13$ & 0,1 \\
\hline solvency ratio & $0,5-0,7$ & 1,23 & 1,35 \\
\hline
\end{tabular}

The traditional methods of equity capital increase should include:

- $\quad$ increase of authorized capital by means of additional issue of shares or change of legal form and entering the IPO market;

- $\quad$ contribution of the founders to the company's property (without changing the charter capital);

- improvement of management with the aim of increasing the efficiency of the company's activity in order to achieve an increase in the growth rate of income, with a smaller growth rate of expenses (use of digital technologies and artificial intelligence);

- ensuring the growth of net profit remaining at the company's disposal (growth of self-financing as a result of a reduction in the share of net profit distributed among owners);

- change in asset structure increase in financial investments into financial instruments on the financial market to generate new cash flows.

At the same time, the introduction of digital methods of management will also contribute to the growth of net profit in the background of a decrease in debt capital, which will have an impact on the capital structure, financial stability of the company and, accordingly, will increase the cost of business.

In conclusion, it should be noted that the current value of the capital structure of JSC "Uralelectromed" is $45 \%$ to $55 \%$, the authors recommend to adjust it towards the optimal value of $40 \%$ to $60 \%$.

\section{Conclusion}

In conclusion, the authors note that under conditions of sustainable development of the industry 4.0 , both domestic and international competition ultimately contributes to catalyzing scientific and technological progress (STP), as it stimulates producers to introduce innovative technologies and produce new types of products, and to use modern resources [13]. Thus, introduction of digital technologies in domestic metallurgical companies will help to reduce costs, optimize capital structure and increase efficiency of companies' activity mainly due to the following directions:

1. Implementation of models based on BigData technologies and artificial neural networks will allow optimizing the supply of raw materials and other resources by calculating their optimal quantity, quality and cost in accordance with the characteristics of the metal products made of these raw materials;

2. The use of machine vision technologies and automation of sampling and qualitative research help to increase the speed of identification of deviations in technological business processes, significantly reduce non-productive costs and recycling of rejected products at the majority of metallurgical processes;

3. The formation of a digital ecosystem of customer interaction based on software products and modules of ERP systems will simplify and accelerate order placement, improve the convenience of tracking the status of execution, ensure control over settlements and effectively manage accounts receivable;

4. Implementation of projects of predictive analysis, provision of repair and maintenance personnel with mobile workstations, use of digital tools for integrated planning and 
intelligent management of spare parts availability, 3D printing technology will improve the quality and efficiency of repair work and other auxiliary business processes;

5. Automation and robotization of administrative business processes (planning, analysis, control) using RPA, digitallabor, intelligentautomation, processmining technologies will significantly reduce the number of personnel in economic and financial services at metallurgical enterprises [14].

Thus, in the context of sustainable development of the industry 4.0 within the framework of the all-Russian digital transformation of the economy, the development of companies and their transition to new standards of management and optimization of generally accepted norms and a set of rules in terms of financial management in general, and money capital management in particular, which as a result will contribute to economic growth and expansion of world economic relations of the country as a whole, becomes increasingly important [15].

Currently, digital transformation initiatives are already being implemented by the world's largest metallurgical companies, such as TataSteel's "Factory of the Future" and RioTinto's "Mine of the Future" projects. Russian metallurgical companies are more conservative in this area, they should follow the example of foreign competitors as soon as possible.

\section{References}

1. V. Kulagin, A. Sukharevski, Y. Meffert, Handbook on Business Digitalization, 48 (2020)

2. Y. A. Dolgikh, Formation and functioning of the financial stability management system of the enterprise (2019), http://science.usue.ru/

3. Digitalization of TMK. What's new ?, Production management. Digital production, 2 (2017), http://www.up-pro.ru/library/

4. Roadmap for the development of end-to-end digital technology "new production technologies", https://digital.gov.ru/

5. G. I. Abdrakhmanova, K. O. Vishnevsky, L. M. Gokhbergi, Report of the HSE Research Institute National Research University. What is the digital economy? Trends, Competencies, Measurement ", XX Apr. int. scientific. conf. on the problems of economic and social development, Moscow, 09.04-12.04.2019 (2019), https://issek.hse.ru/

6. N. Ulyanov, Expert-Ural, 28 (1196) (2020), https://expert.ru/

7. Digitalization of TMK. What's new ?, Production management. Digital production, 2 (2017), http://www.up-pro.ru/library/

8. Official site of LLC "UMMC", https://www.ugmk.com/

9. Official website of $\mathrm{RBC}+$, https://plus.rbc.ru/

10. Digitalization. Practical recommendations for digitalizing a business, 31, 252 (2019)

11. Report on the financial results of JSC Uralelectromed for 2017-2019, JSC Uralelectromed - the city of Verkhnyaya Pyshma

12. Balance sheet of Uralelectromed JSC for 2017-2019, Uralelectromed JSC - the city of Verkhnyaya Pyshma.

13. E.A. Razumovskaya, D.S. Voronov, S.E. Erypalo, D.Yu. Razumovskiy, Fundamental research. Publishing House "Academy of Natural Science", 200

14. J. Reimann, G. Sziebig, IEEE ACCESS, 7 (2019) 
15. E.S. Panfilova, K.A. Shoppert, M.I. Lvova, Proceedings of the 2nd International Scientific conference on New Industrialization: Global, national, regional dimension (SICNI 2018), 191 (2019) 